\title{
Editorial
}

\section{A exigência de direitos humanos em tempos-limite}

Há uma sensação no ar de que vivemos tempos-limite.

A educação liberal, mesmo a de alto padrão científico e tecnológico, não eliminou a exclusão e a barbárie social, pelo contrário, alimentou-a. A voracidade insaciável da economia-política neoliberal corroeu a própria democracia social e mantém-nos presos à ciência moderna baconiana que vê a natureza como fonte de exploração a qualquer custo. Daí, a amplificação dos problemas sociais estruturais - o racismo, o patriarcalismo a pobreza, a fome, a violência - vem apontando, tempos-limite com a crise global sanitária, climática e hídrica.

Nesse quadro, impossível não lembrar Eric Hobsbawm em Era dos Extremos: o breve século XX, 1914-1991, lançado em 1994. Lá, o historiador britânico não só sintetizou as catástrofes e crises daquele período, como já visualizava, no final do século, uma porta aberta para um futuro incerto. O futuro continua incerto; porém, hoje temos uma consciência maior das causas históricas dos grandes problemas socioambientais e indícios mais claros que, no tempo presente, vivemos uma crise paradigmática do modelo de civilização estruturado na modernidade ocidental do norte-global e hoje mundialmente hegemônico.

Aceitar a existência de crise paradigmática hoje é reconhecer a interdependência e a complexidade dos grandes problemas sociais, econômicos, políticos e culturais que ameaçam a humanidade. São de tal magnitude que não se pode resolvê-los separadamente e nem enfrentá-los com modelos culturais e tecnológicos da modernidade que criamos, pois são eles as causas desses grandes problemas.

Mas nem todos pensam assim. Para os 'obrigatoriamente' otimistas, encastelados no poder econômico, supera-se a crise da modernidade com mais modernidade. Ou seja, a modernidade pode resolver os problemas gerados por ela, com mais ciência, tecnologia e desenvolvimento econômico. É preciso apenas um ajuste de rumo civilizatório. Se não puder salvar 
todos, salvam-se os que tiverem mérito para isso, mas tenta-se evitar o caos do 'salve-se-quem-puder'.

Há também os 'profetas do passado' que veem a solução da crise da civilização moderna, na negação da própria modernidade em nome de valores pré-modernos sejam epistemológicos, sejam morais. Eles tentam manter, a todo custo, seu status quo, defendendo estruturas sociais já ultrapassadas pela modernidade. Foi assim, por exemplo, a ação do Santo Ofício que, em pleno Renascimento, impunha a visão teocêntrica a ferro-e-fogo, para manter o poder medieval da Igreja, abalado pelos novos tempos.

A história não para e, muito menos, volta ao passado; mesmo que a curto e médio prazo isso pareça possível. O tempo de crise paradigmática em que vivemos é para ser respeitado e refletido profundamente. É tempo de grandes aprendizagens, pois as mudanças históricas de paradigmas civilizatórios são muito abrangentes do que as 'revoluções' que ocorrem dentro de um mesmo paradigma, como apontou Thomas Kuhn em A estrutura das revoluções científicas (1962). Assim foram as transformações científicas no interior da modernidade, com Newton, Darwin e Freud.

Enfim, nesses tempos-limite, há ainda aqueles 'realisticamente esperançosos'. Para eles - que acreditamos e lutamos por um outro mundo possível - os desafios são enormes, pois nestes tempos perdem-se muitos referenciais. Não temos mais o GPS do curso da história como tinham Marx e Comte, no século XIX. O século XX abalou todas nossas belas certezas modernas. Sabemos hoje muito mais do que não podemos continuar valorizando, do que do perfil da sociedade que precisamos construir.

A transição entre o paradigma medieval e o paradigma moderno demorou pelo menos trezentos anos. Todavia, talvez agora não tenhamos mais tanto o tempo como os modernos tiveram para construir um novo olhar sobre o universo, a natureza e a sociedade em nome de uma nova retórica de poder. Trata-se agora de sobrevivência urgente da humanidade. É isso que crise sanitária, climática e hídrica está gritando em nossos surdos ouvidos.

Essa é a luz que brilha no final do túnel de transição paradigmática: a vida e vida digna para todos sem exceção. E mais, a crise do paradigma da modernidade também nos mostra que a vida humana é parte ínfima e profundamente dependente da vida planetária. E depois que ela tiver passado, nada terá acontecido, já disse Nietzsche lá no século XIX.

Viver em tempo de transição paradigmática, acreditando na luta por uma outra sociedade, exige colocar, como primeiro valor, o direito humano à vida e essa, em equilíbrio com a vida planetária. A partir dessa certeza pode-se reconfigurar os valores da educação em direitos humanos. Assim, educar as novas gerações, cuja responsabilidade é construir a ponte para 
uma nova sociedade, exige cultivar certos valores, hoje fundamentais.

Um deles é a postura diante daquilo que chamamos de 'verdade'. Aceitar a verdade científica moderna não mais como absoluta, não é negá-la ou falseá-la, mas colocá-la em diálogo com outros saberes para ampliar percepção da diversidade e complexidade da realidade socioambiental. Educar hoje exige a humildade da escuta e do aprender juntos na vivência e na reflexão, em lugar do discurso prepotente de quem crê ter a verdade única e absoluta, seja ela científica, política, ou religiosa. Estar aberto às novas possibilidades e aos novos olhares e nossa atual condição humana.

Há outras exigências nesses tempos-limite como: - ressignificar os conceitos de desenvolvimento, de consumo do necessário e do bem viver para todos, que na modernidade visavam especialmente o lucro, o supérfluo e o individualismo; - estimular a cidadania autônoma, ativa, crítica e coletiva; - desenvolver a sensibilidade e a empatia para a convivência nas diferenças sem os padrões culturais cristalizados; e - cultivar a indignação e a luta individual e coletiva contra as desigualdades sociais e todo tipo de opressão e autoritarismo.

Numa palavra, a moralidade humana tem como princípio ético a inclusão e não a seleção natural, que na modernidade ideologicamente chama-se de meritocracia. No novo paradigma a humanidade será para todos ou não será humanidade.

Trilhando esse caminho a Revista Interdisciplinar de Direitos Humanos apresenta nesta edição o dossiê Educação em direitos humanos: resistência e transformação. Na seção de 'artigos diversos', mantemos o foco editorial de 'interdisciplinaridade', trazendo contribuições para pensar os direitos humanos como tema transversal em diferentes áreas do conhecimento acadêmico.

Filosofia. O texto de Ana Santana e Antônio Basílio traz "as reflexões político-filosóficas de Hannah Arendt, volvendo o olhar para a sua teia conceitual sobre a educação e os direitos humanos, a fim de detectar os fios constituintes, capazes de fundamentar os pilares universais".

Direito. No ensaio A escravidão contemporânea no Brasil e a perda da propriedade privada, Pedro Greco e Ricardo Resende debruçam-se "sobre uma discussão do papel da legislação na erradicação da escravidão contemporânea". O estudo nos mostra o "efeito emancipatório dos direitos hu $\neg$ manos na luta antiescravista com o objetivo de melhor vislumbrarmos alguns dos motivos pelo qual pouco prospera a pauta que prevê a perda da pro $\neg$ priedade privada em casos de escravidão contemporânea no Brasil". 
Educação. André Luiz, em Educação em direitos humanos: uma pauta premente na docência e na gestão escolar, relata e analisa uma experiência de formação continuada de docentes e coordenadores pedagógicos, suscitando "novos saberes na prática educativa em direitos humanos".

Educomunicação. Educação em direitos humanos e letramento digital e o artigo de Mara Juliane e Matheus. Nele os autores apresentam as ações e análise dos resultados de uma proposta pedagógica desenvolvida "com discentes das três turmas de primeiros anos do ensino técnico integrado ao ensino médio".

Comunicação: Nesta área temos duas contribuições. Na primeira, as autoras Fabiana de Melo e Maria Dalvi retomam a polêmica ocorrida nas redes sociais, em 2017, "atinente ao recolhimento, pelo Ministério da Educação do Brasil, em 2017, do livro Enquanto o sono não vem". No artigo Polêmicas nas redes sociais, censura literária e silenciamentos sobre abuso sexual: um debate sobre direitos das crianças, "[...] a análise centra-se na questão dos direitos da infância, à luz do tensiona $\neg$ mento sobre a responsabilidade do Estado e da educação pública".

Na segunda contribuição, João da Cruz apresenta um ensaio criativo e crítico para demonstrar, com detalhes, A pedagogia conservadora do cinema de animação. O filme Os Incríveis (Pixar, 2004) é o objeto do estudo.

Engenharia. Com A inserção dos direitos humanos nos cursos de engenharia, os autores Marcos Silvério, Gustavo dos Santos e Márcia de Oliveira fecham esta edição da RIDH, comentando, com dados quantitativos, uma experiência positiva de educação em direitos humanos pelas disciplinas 'Tecnologia Social' e 'Eco $n$ nomia Solidária' de um curso de Engenharia.

Boa leitura!

Prof. Clodoaldo Meneguello Cardoso

Dezembro de 2021. 